\title{
POLICIES FOR PROMOTING DIASPORA INVESTMENT IN COUNTRIES OF ORIGIN
}

\author{
Asst. prof. Sanja Franc, PhD \\ Faculty of Economics and Business, University of Zagreb \\ Trg J. F. Kennedy 6, 10000 Zagreb, Croatia \\ sfranc@efzg.hr \\ Asst. prof. Marina Perić Kaselj, PhD \\ Institute for Migration and Ethnic Studies \\ Trg Stjepana Radića 3, 10000 Zagreb, Croatia \\ marina.peric@imin.hr \\ Ivona Škreblin Kirbiš, PhD \\ Zagreb School of Economics and Management \\ Jordanovac 110, 10000 Zagreb, Croatia \\ ivona.skreblin@zsem.hr
}

\begin{abstract}
Investments from the diaspora and transnational entrepreneurship represent significant areas for potential contribution to national development. Due to the fact that diaspora members have the ability to connect with a wide range of potential partners and supporters in both their countries of origin and countries of residence, and thus create opportunities for investment, trade and outsourcing, developing countries which seek human and financial capital should put more focus on facilitation and promotion measures for collaboration with the diaspora. The main aim of this paper is to define and discuss most commonly used policy measures for promoting diaspora investments and transnational entrepreneurship in developing countries and giving recommendations for diaspora engagement. The analysis indicates that policy measures and the degree to which countries have begun to engage their diaspora vary, while most of them still miss an adequate institutional framework for promoting transnational networks which can be an important channel for fostering business development, job creation and innovation.
\end{abstract}

Keywords: foreign investments; diaspora policy; transnational entrepreneurship 


\section{INTRODUCTION}

Increased migration flows indicate the importance of international migration management. This is even more important when considering the contribution of migrants to national development through diaspora investments and entrepreneurship as well as through migration remittances. Diaspora can be a very useful channel for attracting investments, entrepreneurship and innovation in countries of origin. Diaspora refers to a community of people living outside their country of origin but maintaining a relationship with it. Diaspora is considered to be one of the contemporary global forces and has become an important element of development strategies and policies but also relationship building across countries, regions and continents.

When analyzing the impact of diaspora on economic development, it is often seen through three channels: trade, investments and spillovers. The diaspora population often prefers to consume the products from their countries of origin, thus creating a demand for local goods in foreign markets. Likewise, the diaspora has an important role both as investors in their country of origin and as a stimulus to non-diaspora investors. Diaspora can be an important source of the brain trust, connecting the public and private sectors to expertise not available in the country. Critical elements for facilitating diaspora entrepreneurship and investments are conducive policies, adequate institutional and regulatory environment, access to information, building networks, business training programs and access to funding (Mohamoud and Formson-Lorist, 2014). Developing diaspora engagement policies is becoming increasingly important, particularly when having in mind that diaspora is a potential source of investments, innovation, business and jobs, which is especially valuable for developing and less-developed countries.

Technological advancement and lower transportation costs enabled migrants and diaspora to maintain contact with their countries of origin faster and easier than before, and consequently, have far greater influence. As said, recognizing migrants and diaspora as development actors is now one of the major policy strands considering that migrants and diasporas play a significant role in efforts geared towards advancing the social, political and economic transformation of their countries of origin. It is on this basis that migrants and diaspora are now considered to be the "fourth development aid actors", along with international organizations, governments and mainstream development agencies (Mohamoud and Formson-Lorist, 2014). The involvement of diasporas in their respective countries of origin has not only increased tremendously but has also become diversified, entrenched and broadened in scope, often cutting across different sectors.

Diasporas are considered to be a potential source of investments, knowledge and expertise captured through various forms of collaboration. The concepts of transnationalism or diaspora entrepreneurship are often mentioned in this regard. Transnationalism could be defined as the process by which migrants create and sustain multi-string social and economic relations that link together their societies of origin and residence (Frankenhaeuser and Noack, 2015). Diaspora entrepreneurship is a narrower concept. Diaspora entrepreneurs represent a group of migrants who are entrepreneurs, live outside of their country of origin but stay involved with it. A transnational element of entrepreneurship between one or more countries of destination and origin is implied here (Wolff and Opoku-Owusu, 2016). Diaspora entrepreneurs have the unique ability to exploit opportunities in diverse 
homeland environments to create business and jobs, stimulate innovation, create crossborder social capital and direct political and financial capital towards development.

Diaspora's engagement can also be framed with the so-called "5C model of diaspora capital”, which includes: financial, intellectual, political, cultural and social capital that diasporas can bring to their countries of origin (Chikezie, 2011). However, there is a great divide in diaspora policy between those policymakers who think of diasporas as assets or partners and those who regard them as losses or even threats (Newland and Plaza, 2013). Some governments continue to regard the diaspora as a population that is lost to the country of origin and focus their policy on enticing members to return or on persuading people not to leave. Others pursue bilateral agreements with receiving countries to allow their citizens to migrate legally for work and focus on protecting the rights of migrants. Relatively few governments invest in getting to know and understand their diasporas, maintain meaningful communication with them and find areas of mutual interest for practical collaboration. Some countries expect their diasporas to provide funds or donate their expertise and contacts, without investing much effort in creating incentives for diaspora engagement. Some diaspora members will give back to their country of origin for emotional reasons without asking for much in return, but diaspora policies work best when engagement is a two-way street, in which all parties see clear rewards from collaboration (Newland and Plaza, 2013).

The main aim of this paper is to define and discuss the most commonly used policy measures for promoting diaspora engagement using the example of European countries. The contribution of the paper is in identifying some of the most common challenges and giving recommendations for developing diaspora engagement policies. Research questions are: what are the preconditions for diaspora engagement; what are the main obstacles for diaspora engagement; what is the focus of EU diaspora policies? By reviewing the existing theoretical and empirical literature and studies and with the employment of methods of analysis, synthesis, compilation and deduction, some recommendations and conclusions regarding diaspora policy were given.

\section{LITERATURE REVIEW}

Economies aiming to attract investments from their emigrant diaspora communities, often referred to as diaspora direct investment (see Newland and Tanaka, 2010), are often less economically developed and have scarce financial resources. Investments and transnational entrepreneurship of diaspora have great potential for socio-economic transformation in the country of origin and the country of destination. What is more, an increase in diaspora investment has a significant positive effect on economic development and also has a wider impact of influencing perceptions of the investment climate which can, in turn, lead to an increase in national investment (Gillespie et al., 1999).

According to Teferra (2004), while some diaspora entrepreneurs are permanently returning to their countries of origin, many "circulate" or regularly connect physically and virtually with their country of origin through social networks, electronic bulletin boards and other Internet technologies. Such so-called circular migrants often run business ventures with operations taking place simultaneously in the country of destination and country of origin and traveling between operating locations. Wei et al. (2017) examined the impact 
of Chinese migrants on the economic activities of indigenous Chinese firms from two dimensions: foreign direct investment (FDI) by ethnic Chinese (ECI) and returnees. The findings show that $\mathrm{ECl}$ does have positive and significant spillover effects on the productivity of indigenous Chinese firms and on R\&D activities of indigenous firms whose technology level is not too far from the industrial frontier.

The seemingly pervasive trend of diaspora engagement differs among countries; in some, it is either not taking place, is taking place in a context of competing claims, or only for specific sub-diaspora groups. Mylonas and Žilović (2019) examine how states choose to engage certain segments of a country's diaspora and not others depending on geostrategic interests. They focus specifically on variation in ethnic return migration policy. Through a comparison of post-Cold War policies in Greece and Serbia, they uncover grouplevel variation in state policies pursued toward different groups of ethnic return migrants. They find support for their geostrategic argument where group-level variation in ethnic return migration policies is largely driven by the state elites' ex-ante foreign policy objectives and the role that each particular group is assigned in these strategic objectives based on its territorial origin.

Many developing countries are faced with strong competition on the global market and are focusing on attracting investments targeting just diaspora entrepreneurs. This investment attractiveness strategy is particularly useful for countries with a small domestic market, inadequate infrastructure or other structural deficiencies (Gillespie et al., 1999). In addition to attracting investments or encouraging entrepreneurship in the country of origin, business cooperation with the diaspora is often aimed at improving opportunities for internationalization of business performance. However, this kind of potential for collaboration is often unused due to underdeveloped infrastructure, insufficient connectivity channels and lack of information. Migrants are not always aware of the rapid changes, actual business climate, social or political situations in the country of origin, even with intensive communication with other family members or community of origin (Pirvu and Axiente, 2012). This can be a barrier to starting and operating a business. Projects and measures of facilitation and promotion of cooperation with the diaspora in order to attract investment and business collaboration with the country of origin are therefore of great importance.

Until recently, diaspora engagement activities have been typically uncoordinated (Gamlen, 2014), with governments in the country of origin targeting and interacting with the diaspora in direct and indirect ways. Direct forms of support have included policies specifically targeting the diaspora, typically in terms of finance and support, what Gamlen (2014) refers to as 'diaspora institutions', defined as offices of state dedicated to emigrants and their descendants. Tasks and functions of institutions vary considerably among countries and consequently the level of diaspora involvement as well.

However, involving the diaspora in policymaking can be beneficial as they have the potential to act as change agents in their country of origin (Riddle and Brinkerhoff, 2011) and are considered emerging agents of development (Weinar, 2010). Kshetri (2013) examined the influence of diaspora communities on implementing institutional changes across economies and political systems and found "top-down" approaches. For example, China, a country with a strong state and weak civil society, imposed limitations on the political and social influences of diasporas. On the other hand, India mobilised its diaspora thro- 
ugh religious, social, economic and political associations and these gave rise to enhanced economic opportunities.

There is a significant window of opportunity for diverse migration stakeholders to play a greater role in facilitating and accessing untapped skills and assets of diaspora and migrant investors. Civil society organisations are particularly important stakeholders in the global diaspora engagement processes (Allen, Opoku-Owusu and Rodima-Taylor, 2016). Mayer, Harima and Freiling (2015) find that first-generation diaspora members are likely to have strong informal network ties to their country of origin as they have relationships with family and friends before emigrating, and more formal networks are built over tie through business experience and success. Newland (2010) and Bernal (2014) note that diasporas are involved with their countries of origin either through international organisations or other non-official diplomatic actors. They lobby while transforming and building their collective identity through webpages, discussion groups, social networks, etc.

It should be noted that although much research posits the positive impacts of diaspora engagement, this is not always necessarily the case. Riddle and Nielsen (2011) note that investments made by foreign firms and entrepreneurs are not always efficient and can crowd out domestic investment and displace local firms. This can reduce local competition and lead to lower quality products and inflated prices in local markets (Moran, 1998). Delano Alonso and Milonas (2019) conclude that there is a complex array of factors and actors that shape diaspora politics and challenge the state-centric approach as well as a narrow definition of the term diaspora.

\section{POLICIES FOR DIASPORA ENGAGEMENT}

The need for a transformative migration agenda that modifies existing migrant management systems in accordance with the needs of current large movements of migrants and refugees and that integrates migration with development goals has been emphasized recently at various high-level global development initiatives. Given the size of financial flows originating from the diaspora, governments around the world are becoming increasingly interested in how to channel such flows to foster entrepreneurship, support innovation and develop priority sectors in the economy (Agunias and Newland, 2012). Governments are increasing their regulatory capacities to govern labour migration and relations with diaspora for the mutual benefit of society, migrants and economy.

\subsection{Defining diaspora engagement policy}

Recent global policy discourse reflects a new recognition of the need for a more differentiated engagement in migration flows in diverse contexts and calls for attention to facilitating and harnessing social, economic and cultural contributions of transnational diasporas. Diaspora communities are being recognized as actors of development who can strengthen cooperation between home and host societies.

Governments employ a variety of methods to engage with their diasporas and use different institutional forms at different governmental levels. Diaspora policies can be defined as institutions and practices that apply to members of a country who reside outside its borders. They range from securing the rights and the protection of diaspora members 
while strengthening a sense of national identity to encouraging stronger links to the origin country and contributions to national social and economic development (Frackenhaeuser and Noack, 2015). Diaspora engagement policies are a primary channel through which migrant source states are interacting with their diasporas. Such policies became a part of development strategies engaging also different non-state actors (Mardari, 2017).

Diaspora policies should be based on several criteria (Frackenhaeuser and Noack, 2015; The World Bank, 2011): knowledge about diaspora, tailored diaspora policies, building trust and government-diaspora interconnection. Governments usually have general knowledge about their diasporas, despite the widely lamented lack of data and information. What they may need is specific information that helps them develop better and more targeted policies. They often lack information about the socio-economic background and specific needs of their diaspora, including the type of services to be provided and how the diaspora receives information and maintains ties with the origin country. It is recommended to use both qualitative and quantitative data for assessing diaspora needs. Some of the main challenges in gathering the necessary information are too few outreach channels to inform the diaspora about the opportunity to participate in a survey, inadequate and infrequent information flow and lack of trust between diaspora and government. The diaspora mapping exercise can generate data on knowledge and skills that are available abroad and can enable the government to know what the diaspora is willing to offer and what it expects in return.

Policies that aim to engage diaspora should be specifically tailored based on who the target group is. The practice has shown that strong cooperation between the institution in charge of diaspora engagement and government representations abroad is an important pillar of successful diaspora engagement. Depending on the profile(s) of the diaspora community in a certain country, the engagement strategy and methods need to be tailored accordingly. Coordination between ministries, agencies and other organizations is an important part of steering diaspora engagement strategy. Ensuring links to and analyzing complementarities with other government strategies and policies seems to be largely absent from current processes at the national level.

Governments need to regularly meet with their diasporas in order to keep them informed and involved. Government - diaspora interaction needs to, by definition, go beyond onetime meetings or information solicitation from the side of the government, since interaction implies reciprocity. Efforts should be aimed at supporting joint projects rather than on the return of the diaspora. This means a two-pronged approach that includes both a centralized framework that makes the diaspora feel welcome at home and assures rules for their engagement and institutional space for bottom-up creativity and initiatives. In some opinions, the government's role should be limited since ministries in charge of the diaspora have been largely ineffective and should be focused on facilitating an environment where innovation is encouraged (World Bank, 2011).

\subsection{Diaspora policies in European countries}

There is a clear research gap on emigration in the European Union (EU). The EU is a special case of regional economic integration which enables the mobility of people well beyond the flows of migrant workers. As there are not so many obstacles to labor flows, most EU nationals migrate to another EU country (Weiner, 2014). 
Migration issues and their contribution to development have been discussed for decades, but it can be said that the European Union's first comprehensive approach to migration and development nexus was manifested in a European Commission Communication published in 2005 titled 'Migration and Development: Some concrete orientations'. Concerning the developmental role of diasporas, the European Commission (EC) has funded studies on the potentials of diaspora organizations as partners in development cooperation. Because of the increasing appreciation of contributions by diaspora organizations, the EC is expected to open the budget from non-state actors and local authorities to include diaspora organizations (EC, 2011). Concerning emigration issues, all EU member states have some sort of a strategy towards emigrants, be emigration temporary or permanent. The policies are determined by the history of emigration, the characteristics of contemporary outflows and by the perception of whether a country is a country of immigration or emigration.

Regarding the engagement of diasporas in designing and modification of development policies, most EU members have begun to make certain efforts (Keusch and Schuster, 2012), although these efforts vary. The degree to which countries of Europe have engaged their diaspora and started to develop institutions to support this engagement varies. Most EU responses to emigration on national level include three main categories of actions: traditional diaspora building policies (which focus on cultural and educational outreach); diaspora engagement policies (which focus on citizenship policies); and active emigration policies (which focus on facilitating or or restraining mobility) (Agunias and Newland, 2012).

The majority of European countries have traditional diaspora building policies including offices dealing with their diasporas at the sub-ministerial level; some countries have autonomous offices for the diaspora, while there are countries that have no dedicated office for the diaspora. When a diaspora office is at the sub-ministerial level, it is usually within the ministry of foreign affairs. For those without a dedicated diaspora office, this could imply a variety of stances, ranging from diaspora policy just beginning to be implemented to diaspora offices just being established, which was the case in several countries, to hostility towards the diaspora, which was also the case in a few countries. Most European countries developed diaspora policies after 2000, or their development is still ongoing. Beyond just normal consular functions, many countries cite the assistance of migrants as the goal for their diaspora policies. The practice analyses show that traditional diaspora building policies focus on catering for the cultural needs of the communities of the same cultural background abroad, such as language schools, national curricula schools or active cultural programs for the diaspora. Only Austria, Denmark and Luxembourg have no government strategy nor program focusing on emigrants and the cultural/linguistic support for them (Weiner, 2014). There is a difference in approaches. Central European countries maintain embassy schools, as well as curricula for national minorities abroad, e.g. Lithuanian school programs in Poland (Newland and Tanaka, 2010). The Northern EU countries tend to mix cultural diplomacy with diaspora outreach: the prime example is the network of French or British schools abroad offering full curricula. Following new global trends in diaspora engagement policies for countries with a strong global entrepreneurial outreach, like the UK and the Netherlands, the issue of emigration of human capital has risen higher on the political agenda in the last decade (Mardari, 2017). France is also a good example of actively promoting diaspora entrepreneurship. Baltic countries seem to 
have different approaches to diaspora engagement policies (Weinar, 2014). Most of the new EU member states have taken an active stand towards engaging diaspora, yet the implementation of concrete measures is still lacking.

Furthermore, EU member states predominantly allow dual citizenship. When they do not, the policy has been conceived with regard to naturalized immigrants rather than countryborn emigrants and their descendants, as in the case of Denmark and the Netherlands (Weiner, 2014). One criticism is that most attention to the diaspora is focused on migrant remittances to the detriment of other possible sources of assistance, including diaspora investments in capital markets in their home countries (Newland, 2010).

\section{CHALLENGES AND RECOMMENDATIONS FOR POLICY DEVELOPMENT}

New and increased migration flows impose new challenges for migration and diaspora policies. As noted, diaspora investments and entrepreneurship can be important development factors. Engaging diaspora in national development requires turning investment interest into action and this has to be supported by adequate access to finance, strong public-private partnerships, business training and skills development, as well as other policy measures. Moreover, there is a need to diversify investment instruments and financial products that harness diaspora capital. Governments can attract diaspora investments by offering tax breaks, business training, stable policy environment, facilitation of funds transfer, etc. Furthermore, skills development, training and capacity building are key to stimulate and support the diaspora's contribution to development. Creating formal and informal networks and other information channels is also conducive for diaspora engagement and strengthening relationships.

The engagement of diaspora is not an easy nor automatic task. According to the International Organization for Migration (2012), the "diasporas for development approach" raises a number of major policy challenges such as: how to best acknowledge diasporas' own interests and agenda and integrate them in existing development strategies; how to build trust among stakeholders; how to establish effective working partnerships; how to effectively integrate diaspora contributions into endogenous growth mechanisms (IOM, 2012). Access to capital and technical support are some additional challenges for diaspora engagement (Allen, Opoku-Owusu and Rodima-Taylor, 2016).

Among other major impediments to the effective use of a country's diaspora population is the lack of comprehensive data on their numbers and characteristics. Without knowing the diaspora and its specifics, it is hard to forge close relationships and stimulate it for investments and collaboration with the country of origin. Targeting specific individuals and diaspora groups is also a demanding task which often hinders the potential for efficient collaboration. According to Black and Castaldo (2009) some of the major impediments for diaspora investments are the lack of regulations, inadequate laws and policies. Mardari (2017) found challenges imposed by changing realities in the EU: establishing a new EU funding program in rural and remote areas, especially for local authorities; maintaining the legal status of diaspora organisations; the acceptance of dual citizenship; refugees' integration into the member-states societies; the EU has to implement policies that will help to organise political majorities in support of more proactive migration policy that will 
make Europe more attractive for mobile people with talent and skills; adopting a common approach to protection for displaced persons; close cooperation with third countries.

In order for government and other stakeholders to create and implement a quality diaspora engagement policy it is recommended to: develop sound methodologies for mapping diaspora, apply multiple outreach channels, ensure easier access to legal status in host countries, allow dual citizenship, lower visa cost, coordinate work of different stakeholders and design financial instruments to attract diaspora savings (Newland and Plaza, 2013; Frankenhaeuser and Noack, 2015; Wolff and Opoku-Owusu, 2016). Table 1 summarizes the main recommendations for enabling and promoting diaspora investments in home countries.

\section{Table 1 Recommendations for designing diaspora engagement policy}

\begin{tabular}{|c|c|}
\hline Precondition & Recommendations \\
\hline \multirow{4}{*}{ Enabling environment } & $\begin{array}{l}\text { Enabling legal and regulatory framework, and removing obstacles } \\
\text { (administrative, legal, fiscal, citizenship issues, etc.) }\end{array}$ \\
\hline & Inclusion of civil society efforts in engaging diaspora \\
\hline & Public-private partnerships \\
\hline & Access to property and land, which is often a barrier to investments \\
\hline \multirow{4}{*}{$\begin{array}{l}\text { Financial and technical } \\
\text { support }\end{array}$} & Access to finance (loans, grants) \\
\hline & Provision of investment incentives (tax breaks, variety of financial products) \\
\hline & Business training and skills development \\
\hline & $\begin{array}{l}\text { Technical support and coordination among different actors (agencies, } \\
\text { chambers, etc.) }\end{array}$ \\
\hline \multirow{3}{*}{ Gathering information } & Data collection, research and study of best practices \\
\hline & $\begin{array}{l}\text { Networking, organization of business events for diaspora entrepreneurs, } \\
\text { matching local entrepreneurs, governments and organizations with foreign } \\
\text { counterparts, establishing platforms for information and idea-sharing }\end{array}$ \\
\hline & $\begin{array}{l}\text { Solid reporting lines and exchange of information between ministries and } \\
\text { government institutions in charge of diaspora and consular offices and } \\
\text { institutions abroad }\end{array}$ \\
\hline
\end{tabular}

Source: author's compilation

Besides government and other offices in charge of diaspora, banks and financial institutions, civil society and non-government organizations have important roles in encouraging diaspora investment and supporting entrepreneurship initiatives.

\section{CONCLUSION}

Developing and implementing national policies to manage migration issues such as collaboration with diaspora, preventing brain drain or potentially attracting migrants back to the country of origin becomes increasingly important at the time of increased migration flows. With the development of technology, digitalization of the economy and other new global trends, human capital and innovation are some of the most important sources of 
growth. The emigration of highly skilled labor, therefore, represents a challenge, particularly for developing or less developed countries. Attracting highly skilled labor and diaspora brain trust are now seen as an important part of national development strategies, especially in the era when technological progress significantly facilitated the linkage and communication between migrants and their countries of origin, thus changing the possibilities of cooperation and exchange of information and experiences. Diaspora can be a valuable source of capital, skills, knowledge and expertise. What is more, diaspora entrepreneurship is becoming recognized as a valuable channel for creating jobs, skills and innovations in the country of origin. Migrants and diaspora may have entrepreneurial ambitions or otherwise invest in their country of origin and thus, contribute to national growth and development. By forming relationships in two or more countries, entrepreneurs can access a greater variety of opportunities and information on assets, customers, suppliers, and partners than by operating in only one country, which is solid motivation for transnational endeavors. The importance of involving diaspora in international development cooperation is accepted in most European countries and several of them have already devised programmes and schemes to facilitate this process. Yet, diaspora engagement is not a simple task. Governments are expected to target the right groups, gather information about diaspora, facilitate collaboration, build trust and promote investments using available measures. A common practice for promoting economic and political collaboration between countries of residence and of origin includes capacity building for diaspora organizations; organizational development for diaspora associations; and activities that stimulate return migration. Policies for the inclusion of diaspora vary among countries, but there are some common characteristics as they focus on preserving cultural heritage, funding schemes for the development of NGOs and building networks. Recommendations for designing policies for diaspora engagement in national development include, firstly, mapping diaspora and getting to know their specific features, interests and needs, then, ensuring supportive and stable business and legal environment, ensuring access to capital and business training as well as access to information. Diaspora or foreign directs investments can never replace national development initiatives and investments and should be considered as a complement to national resources and policies. For future research, it would be useful to analyze and compare diaspora policy measures across selected countries to find best practices, and to include the institutions that should be involved in market development through cooperation and involvement of the diaspora. 


\title{
STRATEGIJE PROMOVIRANJA ULAGANJA DIJASPORE U NJIHOVE ZEMLJE PORIJEKLA
}

\author{
doc.dr.sc. Sanja Franc \\ Ekonomski fakultet Sveučilišta u Zagrebu, \\ Trg J.F. Kennedyja 6, Zagreb, Hrvatska \\ E-mail:sfranc@efzg.hr \\ dr.sc. Marina Perić Kaselj \\ Institut za migracije i narodnosti \\ Trg Stjepana Radića 3, Zagreb, Hrvatska \\ E-mail: marina.peric@imin.hr \\ dr.sc. Ivona Škreblin Kirbiš \\ Zagrebačka škola ekonomije i managementa \\ Jordanovac 110, Zagreb, Hrvatska \\ E-mail: ivona.skreblin@zsem.hr
}

\section{SAŽETAK}

Ulaganja dijaspore $i$ transnacionalno poduzetništvo predstavljaju značajna područja potencijalnog doprinosa nacionalnom razvoju. S obzirom na činjenicu da dijaspora ima više mogućnosti povezivanja sa širokim spektrom potencijalnih partnera, kako u svojim zemljama podrijetla, tako i u zemljama imigracije te time i stvaranja prilika za ulaganja, trgovinu i outsourcing, zemlje u razvoju kojima nedostaje ljudskog i financijskog kapitala trebale bi se više usmjeriti na projekte i mjere poticanja suradnje s dijasporom. Glavni cilj ovog rada je definirati i raspraviti glavne i najčešće korištene mjere politika za poticanje ulaganja dijaspore i transnacionalnog poduzetništva u zemljama u razvoju sa svrhom davanja preporuka za uključivanje dijaspore. Provedena je analiza ukazala da su mjere poticanja i stupanj uključivanja dijaspore različiti među zemljama, a u većini njih i dalje nedostaje odgovarajući institucionalni okvir za promicanje transnacionalnih mreža koje mogu biti važan kanal razvoja poduzetništva, radnih mjesta i inovacija.

Ključne riječi: inozemna ulaganja; dijaspora; transnacionalno poduzetništvo 


\section{REFERENCES}

1. Agunias, D. R. and Newland, K. (2012). Developing a Road Map for Engaging Diasporas in Development: $A$ handbook for policymakers and practitioners in home and host countries. Geneva: IOM and Migration Policy Institute Publishing.

2. Allen, C., Opoku-Owusu, S. and Rodima-Taylor, D. (2016). Diaspora and migrant investment and national development: building on the nexus. MADE thematic report. Migration and development Civil Society Network.

3. Bernal, V. (2014). Nation as network: diaspora, cyberspace and citizenship. Chicago: University of Chicago Press.

4. Black, R. and Castaldo, A. (2009). Return migration and entrepreneurship in Ghana and Cote d'Ivoire: the role of capital transfers. Tijdschrift voor Economische en Sociale Geografie, 100(1), 44-58.

5. Chikezie, C. E. (2011). Reinforcing the contribution of African disporas to development. In Plaza, S., Ratha, D. (Eds.) Diaspora for development in Africa. Washington: The World Bank.

6. Délano Alonso, A. and Mylonas, H. (2019). The microfoundations of diaspora politics: unpacking the state and disaggregating the diaspora. Journal of Ethnic and Migration Studies, 45(4), 473-491.

7. European Commission (2011). Migration and development. Communication from the Commission to the Council, the European Parliament, the European Economic and Social Committee and the committee of the Regions. Brussels, European Commission. European Commission Staff Working Paper, COM 743 final. Brussels.

8. Frankenhaeuser, M. and Noack, M. (2015). Promoting diaspora engagement. What have we learnt? Working paper. Vienna: International Centre for Migration Policy Development.

9. Gamlen, A. (2014). Diaspora institutions and diaspora governance. International Migration Review, 48(1), 180-217.

10. Gillespie K., Riddle, L., Sayre. E. and Sturges, D. (1999). Diaspora Interest in Homeland Investment. Journal of International Business Studies, 30(3), 623-634.

11. International Organization for Migration (2012). Developing a Road Map for Engaging Diasporas in Development. Geneva: IOM, Washington: Migration Policy Institute.

12. Keusch, M. and Schuster, N. (2012). European good practice examples of migration and development initiatives, with a particular focus on diaspora engagement. Vienna: Institute for International Dialogue and Cooperation. Retrieved from http://www.mirovniinstitut.si/data/ tinymce/Projekti/comide_lana/CoMiDe_European\%20Good\%20Practice\%20Study-screen. pdf (7 June, 2019).

13. Kshetri, N. (2013). The diaspora as a change agent in entrepreneurship-related institutions in sub-Saharan Africa. Journal of Development Entrepreneurship, 18(3), 1-27.

14. Mardari, V. (2017). European Union and diaspora engagement policy within changing realities. CEW Working Papers, IX(3), 213-226.

15. Mayer, S.D., Harima, A., Freiling, J. (2015). Network benefits for Ghanaian diaspora and returnee entrepreneurs. Entrepreneurial business and economics review, 3(3), 95-122.

16. Mohamoud, A. and Formson-Lorist, C. (2014). Diaspora and migrant entrepreneurs as social and economic investors in homeland development. Migration and development civil society network. Retrieved from http://www.madenetwork.org/sites/default/files/FINAL\%20 MADE\%20Policy\%20Paper_MigrantsEntrepreneurship_Dec2014.pdf (7 June, 2019). 
17. Moran, T. H. (1998). Foreign Direct Investment and Development: The New Policy Agenda for Developing Countries and Economies in Transition. Washington DC: Institute for International Economics.

18. Mylonas, H. and Žilović, M. (2019). Foreign Policy Priorities and Ethnic Return Migration Policies: Group-level Variation in Greece and Serbia. Journal of Ethnic and Migration Studies, 45(4): 613-635.

19. Newland, K. (2010). Voice after exit: Diaspora advocacy. Washington: Migration Policy Institute.

20. Newland, K. (Ed.) (2010). Diasporas: New Partners in Global Development Policy. Washington, DC: Migration Policy Institute.

21. Newland, K. and Plaza, S. (2013). What we know about Diasporas and economic development. Policy Brief. Washington: Migration Policy Institute.

22. Newland, K. and Tanaka, H. (2011). Mobilizing Diaspora Entrepreneurship for Development. Washington: Migration Policy Institute.

23. Pirvu, R. and Axiente, G. (2012). Return migration - reasons, consequences and benefits, Annals of the University of Petroşani. Economics, 12(4), 193-202.

24. Riddle, L. and Brinkerhoff, J. (2011). Diaspora entrepreneurs as institutional change agents: The case of Thamel.com. International Business Review, 20(6), 670-680.

25. Riddle, L. and Nielsen, T. J. (2011). Policies to strengthen diaspora investment and entrepreneurship: Cross-national perspectives. In Kashyap, A. Montes, M. and Sharma, K. (Eds) Realizing the potential of diasporas to reduce poverty and enhance development. New York: United Nations Publications.

26. Smallbone, D., Kitching, D. and Athayde R. (2010). Ethnic diversity, entrepreneurship and competitiveness in a global city. International Small Business Journal, 28(2), 174- 190.

27. Teferra, D. (2004). Brain circulation: Unparalleled opportunities, underlying challenges and outmoded presumptions. Symposium on International Labour and Academic Mobility: Emerging Trends and Implications for Public Policy, World Education Services. Center for International Higher Education, Boston College, Toronto.

28. Wei, Y., Liu, X., Lu, J. and Yang, J. (2017). Chinese Migrants and their Impact on Homeland Development. World Economy, 40, 2354-2377.

29. Weinar, A. (2010). Instrumentalising diasporas for development: International and European policy discourses. In R., Baubock, Faist, T. (Eds) Diaspora and Transnationalism: Concepts, Theories and Methods. Amsterdam: Amsterdam University Press.

30. Weiner, A. (2014). Emigration Policies in Contemporary Europe. CARIM-East Research Report 2014/01. Robert Schuman Centre for Advanced Studies, San Domenico di Fiesole (FI): European University Institute

31. Wolff, V. and Opoku-Owusu, S. (2016). Diaspora engagement on country entrepreneurship and investment. Background paper. International center for migration policy development. Paper prepared for the Rabat Process Thematic Meeting on Diaspora Engagement Strategies: Entrepreneurship and Investment, 5-6 October in Bamako, Mali.

32. World Bank (2011). Harnessing the Diaspora for development in Europe and Central Asia. Migration and remittances learning. Discussion Series. Washington: The World Bank. 